\title{
The Effect of Humic Acid on Nutrient Composition in Broad Bean (Vicia faba L.) Roots
}

\author{
Şener AKINCI'), Tamer BÜYÜKKESKINN2), Ahmet EROĞLU'), Birsen Eygi ERDOĞAN(4) \\ 1) Marmara University, Faculty of Arts and Sciences, Department of Biology akinci@marmara.edu.tr) \\ 2) Marmara University, Institute of Pure and Applied Sciences \\ 3) Izmir Institute of Technology, Department of Chemistry \\ 4) Marmara University, Faculty of Arts and Sciences, Department of Mathematics
}

\begin{abstract}
Humic acids promote the conversion of mineral nutrients into forms available to plants. It also stimulates seed germination and viability, and its main effect usually being more prominent in the roots. The objective of this study was to determine of the influence of humic acid on broad bean (Vicia faba L.) cultivar 'Eresen 87' on root growth and development as well as nutrient uptake, during investigation in a pot experiment. Treatment with leonardite, as humic acid source positively affected both germination and harvesting, enhancing root length and biomass. Humic acid (HA) caused significant increase of fresh (RFW) and dry (RDW) weights by $30.1 \%$ and $56.6 \%$ of broad bean roots, respectively. Flame photometer and atomic absorption spectrophotometry analyses revealed that K content was major nutrient among the tested elements. Humic acid increased the contents of $\mathrm{Na}$ and $\mathrm{K}$ significantly. The content of $\mathrm{Ca}$ and $\mathrm{Fe}$ was not significantly increased whereas $\mathrm{Cu}, \mathrm{Mn}$ and $\mathrm{Zn}$ content decreased under HA treatment.
\end{abstract}

Keywords: Humic acid, nutrients, Vicia faba L. broad bean, roots.

\section{Introduction}

Broad bean is nutritionally important vegetable all over the world, containing $20-36 \%$ protein for human and animal consumption. While in Turkey 47.000 ton dry broad bean has been produced, total production is up to 4438 510 ton in the world (Anon., 2005).

Humic acids are characterized as a heterogeneous natural resource, ranging in colour from yellow to black, having high molecular weight, and resistance to decay. Humic acid, as a commercial product contains $44-58 \% \mathrm{C}$, $42-46 \% \mathrm{O}, 6-8 \% \mathrm{H}$ and $0.5-4 \% \mathrm{~N}$, as well as many other elements (Larcher, 2003; Lee and Bartlette, 1976). It improves soil fertility and increases the availability of nutrient elements by holding them on mineral surfaces. The humic substances are mostly used to remove or decrease the negative effects of chemical fertilizers from the soil and have a major effect on plant growth, as shown by many scientists (Linchan, 1978; Ghabbour and Davies, 2001; Pal and Sengupta, 1985).

Humic acid has an essential role in agricultural processes. It increases cation exchange capacity and enhances soil fertility, converting the mineral elements into forms available to plants (Stevenson, 1994). Humic substances lead to a greater uptake of nutrients into the plant root and through the cell membrane (Y1lmaz, 2007; Tipping, 2002; Kulikova et al., 2005). Humic acids show a spongelike tampon character in the wide $\mathrm{pH}$ scale, its activity may be changed by various $\mathrm{pH}$ levels but neutralizes soil $\mathrm{pH}$, so many trace elements become available to the plant (Yilmaz, 2007). Humic substances can break the bonds between phosphate and the iron ions in between acid soils and in calcium and iron ions in alkaline soils (Stevenson, 1994).

The available studies have revealed correlations between the root growth and development and the uptake of some nutrients. For instance, humic acid caused increases in length and dry weight of maize plant roots, and enhanced the uptake of nitrogen, phosphorus, $\mathrm{K}^{+}, \mathrm{Ca}^{2+}$, $\mathrm{Cu}^{2+}, \mathrm{Mn}^{2+}, \mathrm{Zn}^{2+}$ and $\mathrm{Fe}^{3+}$ (Eyheraguibel et al., 2008). Humic substances increased root length in Helianthus annuus L. (Kolsaric1 et al., 2005), in maize roots, and uptake of micronutrients such as $\mathrm{Zn}^{2+}, \mathrm{Fe}^{3+}, \mathrm{Mn}^{2+}$ and $\mathrm{Cu}^{2+}$ (Sharif et al., 2002), as well as root dry weight in tomato and cucumber (Atiyeh et al., 2002); in ryegrass, humic substances stimulated root development and enhanced nitrogen, $\mathrm{K}^{+}, \mathrm{Cu}^{2+}$ and $\mathrm{Mn}^{2+}$ content (Bidegain et al., 2000); and increased root fresh and dry weight (Dursun et al., 1999). According to Adani et al. (1998) commercial humic acid affected tomato root fresh and dry weights of tomato as well as iron content, depending on the source of the humic acid. The two concentrations (20 and $50 \mathrm{mg} / \mathrm{L}$ ) of humic acid, resourced from fertiliser, caused iron to increase to $113 \%$, and $123 \%$ whereas humic substance derived from leonardite increased iron content to $135 \%$ and $161 \%$ in tomato roots. David et al. (1994) reported that more $\mathrm{K}^{+}$ 
82

and $\mathrm{Ca}^{2+}$ accumulation occurred in tomato roots grown under greenhouse conditions.

This investigation was undertaken to examine the effects of humic acid on the absorption of $\mathrm{Na}^{+}, \mathrm{K}^{+}, \mathrm{Ca}^{2+}$, $\mathrm{Cu}^{2+}, \mathrm{Fe}^{3+}, \mathrm{Mn}^{2+}$ and $\mathrm{Zn}^{2+}$ by roots of broad bean seedlings grown in the pots experiment. The hypothesis was that the nutrients absorbed from the soil in the presence of humic acid, which can regulate soil $\mathrm{pH}$, should enhance the uptake of beneficial elements in the rhizosphere of broad bean.

\section{Materials and methods}

Design of experiment and germination of broad bean seeds

The experiments were conducted with broad bean cultivar 'Eresen 87' in growth room conditions of the Department of Botany, Marmara University, during the period from November 2007 to 2009. The seeds were obtained from the Aegean Agricultural Research Institute, Izmir. Humic acid as the commercial product "Black Gold", sourced from leonardite was kindly provided by HEKTAŞ LTD., İstanbul.

The cultivar seeds after imbibition in distilled water, were germinated in separate petri dishes, prepared by placing disks of filter paper in the base of each, arranged for randomised treatment as control $\mathrm{HO}$ (Hoagland) and experimental (HA). The HO and HA (humic acid) treatments were applied to the seeds as full strength Hoagland solution (Hoagland-Arnon, 1950) and humic acid (10 $\mathrm{ml} / \mathrm{l}$ ) added to Hoagland solutions respectively. The solutions used in the experiment are as formulated in Tab. 1 and 2. After germination the seeds were transferred to single pots ( $10 \mathrm{~cm}$ in diameter) containing $280 \mathrm{~g}$ sterilised (Gardol) compost media after $\mathrm{pH}$ was adjusted to 4.5 by adding $\mathrm{H}_{2} \mathrm{SO}_{4}$ and mixed throughly.

The pots were set up in a completely randomized block (Mead and Curnow, 1983) at $23 \pm 2{ }^{\circ} \mathrm{C}$ (Eriş and Şeniz, 1997), 55 $\pm 5 \%$ moisture and exposed to 4000-4200 lux light intensity for $14 / 10 \mathrm{~h}$ day and night periods respectively. For a period of two months the control and experimental sets of replicate plants, were given a three day intervals, with $30 \mathrm{ml}$ Hoagland (HO) or of Hoagland +10 $\mathrm{ml} / \mathrm{l}$ humic acid (HA) solutions respectively.

\section{Nutrient analyses}

For the determination of element composition of the roots, at the harvesting time, the roots of $\mathrm{HO}$ and $\mathrm{HA}$ treated plants were excised and their fresh and dry weights determined by the following methods (Roberts et al., 1993; Beadle, 1993, Mackey and Neal, 1993).

The nutrient analyses samples were perepared by wet ashing method described by Kaçar, (1972). The dried samples were crushed using mortar and pestle. Each powdered sample was transferred to an erlenmeyer flask, to which was added $6 \mathrm{ml}$ nitric acid + perchloric acid solutions.
The samples were kept for 30 minutes at $40 \mathrm{oC}$ in water bath for digestion and the solution removed by heating at $150-180{ }^{\circ} \mathrm{C}$ until reduced to $1 \mathrm{ml}$ extract. This residue was dissolved with distilled water and made up to $100 \mathrm{ml}$ in standard flasks. The samples for determination of $\mathrm{Na}^{+}$, $\mathrm{K}^{+}, \mathrm{Ca}^{2+}$ and $\mathrm{Cu}^{2+}, \mathrm{Fe}^{3+}, \mathrm{Mn}^{2+}$ and $\mathrm{Zn}^{2+}$ were analysed using flame photometers (FP) (Jenway) and flame atomic absorption spectrophotometers (FAAS) Varian Liberty Series II atomic emission spectrophotometers (ICP-AES) with air- $\mathrm{C}_{2} \mathrm{H}_{2}$ respectively.

\section{Statistical analyses}

The data obtained from the experiments with 6 replicates set up in a randomised arrangement, were subjected to NCSS (2004) analysis for two-samples for T test range test at $5 \%$ level to determine significance of differences between means. Means are indicated with standard error $( \pm$ s.e.).

\section{Results and discussion}

Tab. 1. The ingredients of humic acid solutions

\begin{tabular}{cc}
\hline Ingredients & Volume $(\% \mathrm{w} / \mathrm{w})$ \\
\hline Total organic substances & 9.5 \\
Total humic acid + Fulvic acid & 18.4 \\
Water soluble $\mathrm{K}_{2} \mathrm{O}$ & 4.0 \\
\hline $\mathrm{pH}$ & $10-12$ \\
\hline
\end{tabular}

Tab. 2. Experimental groups and solutions

\begin{tabular}{|c|c|}
\hline Groups & Ingredients \\
\hline $\begin{array}{c}\mathrm{HO} \\
(\text { Control })\end{array}$ & $\begin{array}{l}\text { Full strength of Hoagland: (Hoagland and Arnon, } \\
1950) 5 \mathrm{ml} \mathrm{Ca}\left(\mathrm{NO}_{3}\right)_{2} \cdot 4 \mathrm{H}_{2} \mathrm{O}, 5 \mathrm{ml} \mathrm{KNO} \mathrm{KN}_{3}, 2 \mathrm{ml} \\
\mathrm{MgSO}_{4} \cdot 7 \mathrm{H}_{2} \mathrm{O}, 1 \mathrm{ml} \mathrm{KH}_{2} \mathrm{PO}_{4}, 2 \mathrm{ml} \mathrm{FeEDTA} \text { for } \\
\text { micro nutrients; } 1 \mathrm{ml} \text { from the stock of } \mathrm{MnSO}_{4} \mathrm{H}_{2} \mathrm{O} \text {, } \\
\mathrm{Zn}\left(\mathrm{NO}_{3}\right)_{2} \cdot 6 \mathrm{H}, \mathrm{O}, \mathrm{Cu}\left(\mathrm{NO}_{3}\right)_{2} .3 \mathrm{H}, \mathrm{O}, \mathrm{H}_{3} \mathrm{BO}_{3}, \mathrm{~K}_{2} \mathrm{MoO}\end{array}$ \\
\hline $\begin{array}{l}\text { HA (Humic } \\
\quad \text { acid) }\end{array}$ & $\begin{array}{l}10 \mathrm{ml} \mathrm{humic} \text { acid solution was added to } \\
\text { Hoagland and made up } 1 \text { liter. }\end{array}$ \\
\hline
\end{tabular}

\section{Humic acid effect on root growth and development}

The statistically evaluated results for root parameters of broad bean in both Hoagland ( $\mathrm{HO}$ ) and Hoagland + Humic acid (HA) treatments were presented in Tab. 3.

Among plant samples, significant differences regarding effect of humic acid concentration and origin are mostly associated with crop root growth and development. Lulakis and Petras (1995) stated that water uptake increases nutrient absorbance by the roots in the presence of humic acid, which enhances the development of lateral roots.

In fact, different concentrations of humic acids originating from fertilisers and leonardite have variously increased root fresh weights in tomato (David et al., 1994). These results are supported by our observations of the significant increasing of $30.1 \%(p=0.000187<\alpha=0.05)$ in fresh root 
Tab. 3. The effect of humic acid on broad bean (Vicia faba L.) roots

\begin{tabular}{ccc}
\hline Parameters & HO & HA \\
\hline Root fresh weight $(\mathrm{g})$ & $3.06 \pm 0.13$ & $3.98 \pm 0.13^{*}$ \\
\hline Root dry weight $(\mathrm{g})$ & $0.30 \pm 0.02$ & $0.47 \pm 0.02^{*}$ \\
\hline
\end{tabular}

Means of 6 replicates, \pm : standard error, HO: Hoagland treatment (control), HA: Humic acid treatment

*: Significantly different from control (HO).

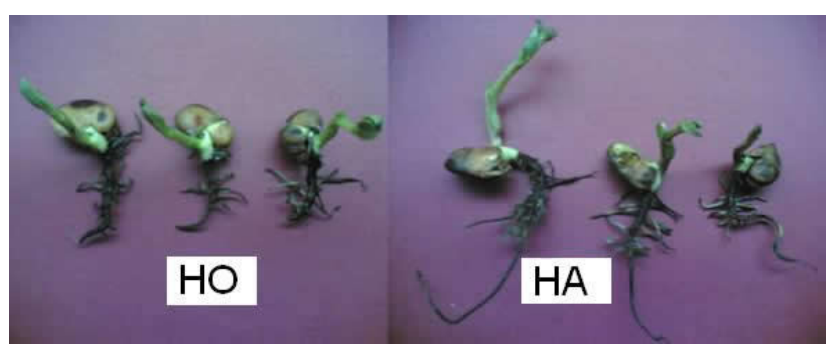

Fig. 1. Vicia faba L. seeds at the end of germination stage treated with $\mathrm{HO}$ : Hoagland and HA: Humic acid

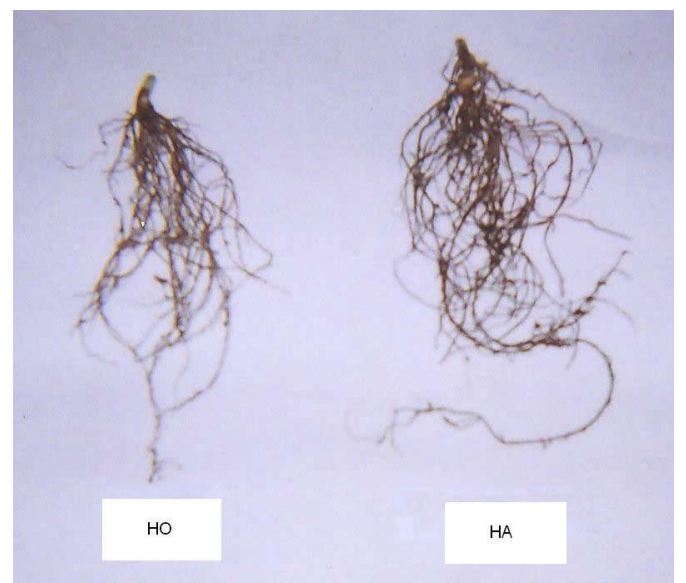

Fig. 2. Vicia faba L. seeds at harvesting stage treated with HO: Hoagland and HA: Humic acid

weight of broad bean. Similar results were reported for maize in which RFW increased by $48.8 \%$ (Eyheraguibel et al., 2008); and by significant increases in egg plants and tomato (Dursun et al., 1999); as well as stimulated root development in ryegrass plants (Bidegain et al., 2000).

Some reports stated that increasing of root density resembles the hormonal activity of plant auxine which also cause increasing root formation and weight (O'Donnell, 1973; Muscolo et al., 1999; Canellas et al., 2002). According to Zandonadi et al., (2007), in maize, IAA and humic acid can enhance the lateral root development by activating cell membrane and the $\mathrm{H}^{+}$pump in the tonoplast of plant cells.

In terms of RDW humic acid in broad bean showed a significant increase of $56.6 \%$ compared to control treatment in broad bean roots. The results were supported by studies on roots of maize (Erdal et al., 2000; Sharif et al., 2002; Eyheraguibel et al., 2008), in marigold, pepper, tomato and strawberries (Arancon et al., 2003), egg plant and tomato (Dursun et al., 1999), tomato (David et al.,
1994; Adani et al., 1998), tomato and cucumber (Atiyeh et al., (2002), and in wheat (Malik and Azam, 1985). Some reports explain these positive effects in terms of ability of humic acid to hold the nutrients in rhizosphere. Humic acids enhance the absorbance capacity of nutrients of the roots by having carboxyllic and phenolic groups and increasing $\mathrm{H}^{+}$-ATPase activity in the root cells (Canellas et al., 2002)

\section{Effect of humic acids on nutrient contents of the roots}

The concentration of different nutrients, namely, potassium, copper, sodium, calcium, iron, zinc and manganese, were determined in broad bean plants grown under in both Hoagland ( $\mathrm{HO}$ ) and Hoagland+Humic acid (HA) solutions. The results obtained at the harvesting stage of growth were evaluated as gram in dry weight. The nutrient concentrations among the $\mathrm{HO}$ and $\mathrm{HA}$ treatments are presented in Fig. 3.

\section{Potassium/Sodium}

$\mathrm{K}^{+}$is an major cationic nutrient which is essential to all plant life mostly in terrestrial plants. It also activates crucial enzymatic reactions and contributes to the osmotic pressure of the vacuole, which helps to maintain structural rigidity.

Potassium content was clearly higher than that of $\mathrm{Na}^{+}$ found in roots (Fig. 3. B). The highest concentrations of $\mathrm{K}^{+}$accumulated in roots in the presence of humic acid. The increase of $\mathrm{K}^{+}$in HA differed significantly $(111.4 \%$; $p=0.002<\alpha=0.05)$ from control seedlings. The findings supported the study on tomato root by David et al., (1994). According to Samson and Visser (1989) the reason for the increase of $\mathrm{K}^{+}$is humic acid, which stimulates the permeability of cell membranes. We suggest that compared to $\mathrm{HO}$ treatment of broad bean root, the significant increase of $\mathrm{K}^{+}$content was related to $\mathrm{K}^{+}$ingredients being released freely and easily absorbed by plants roots.

As a factor contributing to salinity, sodium has an important negative effect on salt sensitive plants such as broad bean. However, in our experiment the ratio of sodium was increased 1.86 times in plants treated with humic acid, where $\mathrm{K}^{+}$increased 2.11 times compared to control values. The ratios of $\mathrm{K}^{+}: \mathrm{Na}^{+}$remained almost unchanged in the roots of broad bean that found as 4.30 and 4.96 in $\mathrm{HO}$ and $\mathrm{HA}$ values respectively. These results support suggestions that tolerance to sodium accumulation may be more related to the $\mathrm{K}^{+}: \mathrm{Na}^{+}$ratio in the cell than to the absolute $\mathrm{Na}^{+}$concentration (Benzyl and Reuveni, 1994; Qian et al., 2001) so, this gradual increase in $\mathrm{Na}^{+}$may not have caused any injuries, but, more probably maintains, $\mathrm{Na}^{+}$balance between cytoplasm and vacuole (Subbarao et al., 2001) and protects cytoplasmic membranes under saline soil (Hare et al., 1998; Rehman et al., 2002; Sakamoto and Murata, 2002).

Although sodium ions are not essential for the growth of most land plants which do not seem to have transport 
84

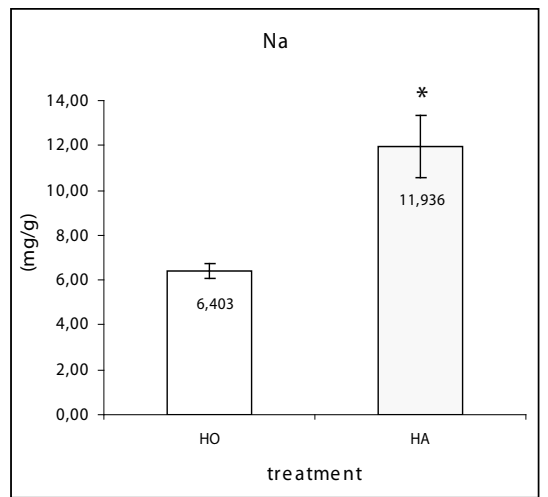

A

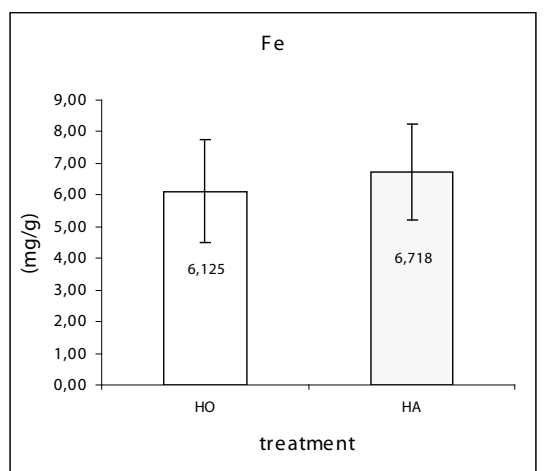

$\mathrm{D}$

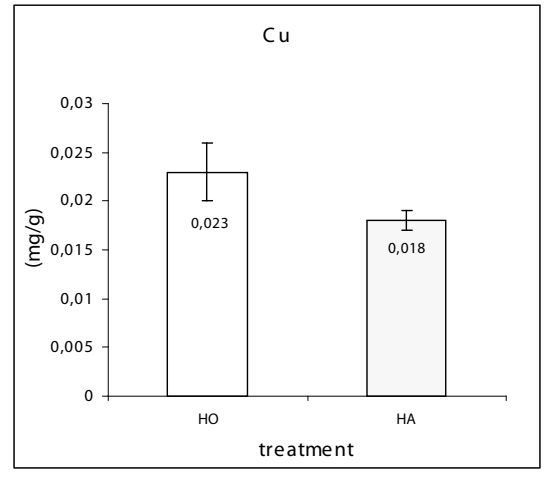

G

Fig. 3 Flame and atomic absorption spectrophotometer determination of nutrient composition of Vicia faba L. roots. * : Significantly different from $\mathrm{HO}$.

systems specifically for $\mathrm{Na}^{+}$uptake, $\mathrm{Na}^{+}$can still enter plant cells via several routes (Fig. 3. A). Current evidence suggests that $\mathrm{Na}^{+}$enters root cells mainly through various cation channels. These channels could be voltage-dependent cation channels or voltage-independent cation channels (VIC). Among them, VIC channels are considered the major route for $\mathrm{Na}+$ entry into plant cells (Amtmann and Sanders, 1999; Schachtman and Liu, 1999; Tyerman and Skerrett, 1999; White, 1999).

The $\mathrm{Na}^{+}$content of under ground parts of broad bean plants was found as $86.4 \%$ which increased significantly $(p=0.002<\alpha=0.05)$. Since the concentration of $\mathrm{Na}^{+}$in the experiment derived mostly from the salt of $\mathrm{Na}_{2} \mathrm{MoO}_{4}$

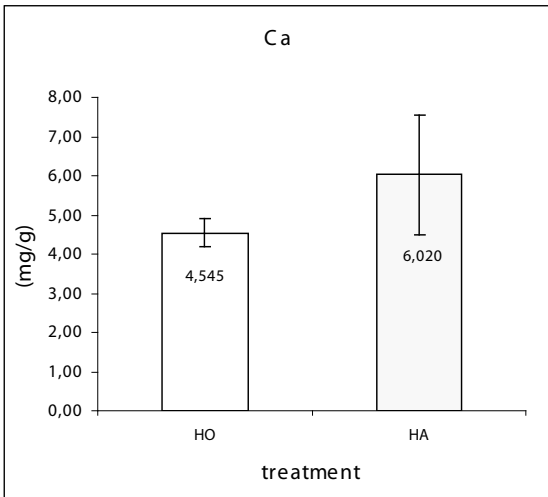

C

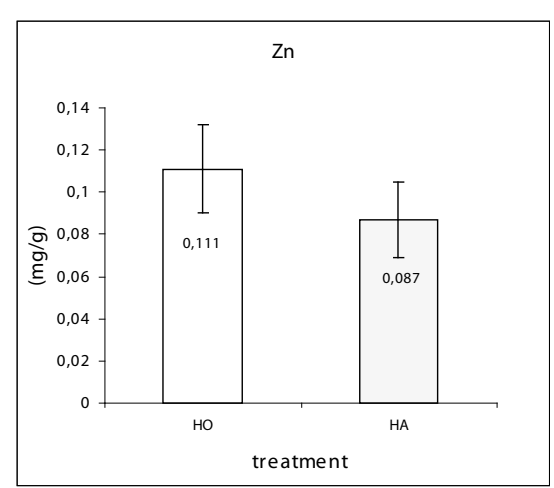

F

in both treatments ( $\mathrm{HO}$ and $\mathrm{HA}$ ), a much higher $\mathrm{Na}^{+} \mathrm{ab}-$ sorption than that in the cytosol of root cells, $\mathrm{Na}^{+}$movement into root cells is passive (Valdrigh et al., 1996). The increase of $\mathrm{Na}^{+}$may be related to humic acid causing greater root permeability by increasing lateral root development and total root bio-mass.

\section{Calcium}

Humic acid increased $\mathrm{Ca}^{2+}$ content $32 \%$ however this did not significantly differ from $\mathrm{HO}$ (Fig. 3. C).

The available research revealed that $\mathrm{Ca}^{2+}$ content increased in tomato (David et al., 1994). The reason of $\mathrm{Ca}^{2+}$ content relatively lower than $\mathrm{K}^{+}$was considered to be directly related to antagonistic effects of $\mathrm{Ca}^{2+}$ on $\mathrm{K}^{+}$ (Mathers, 2002), and $\mathrm{Na}^{+}$(Türüdü,1988). According to Türüdü, (1988), $\mathrm{Ca}^{2+}$ absorption can be relatively preferred to $\mathrm{K}^{+}$. In the experiment its content was found to be 10 fold higher than that of $\mathrm{Ca}^{2+}$ and excessive $\mathrm{K}^{+}$content can inhibit the absorption of $\mathrm{Mg}^{2+}$ and $\mathrm{Ca}^{2+}$ from the roots.

\section{Iron/Zinc}

The $\mathrm{Fe}^{3+}$ content in HA did not show any significant differences compared to $\mathrm{HO}$ treatment of broad bean root (Fig. 3. D). Lee and Bartlett (1976) found that, in maize roots, $\mathrm{Fe}^{3+}$ concentration was decreased after applying HA. In tomato plants grown in greenhouse conditions, applying humic acid increased the $\mathrm{Fe}^{3+}$ content in its roots (David et al., 1994). Our results support this increase 
however, without any significant differences, related with the reduction from $\mathrm{Fe}^{3+}$ to $\mathrm{Fe}^{2+}$ and humic can chelate $\mathrm{Fe}^{3+}$ to change its form to be absorbed.

There appears to be no information relating to zinc accumulation in broad bean root, however $\mathrm{Zn}^{2+}$ absorption greatly varied in both plant species and growth media (Kabata-Pendias and Pendias, 2001). Despite it being stated that absorption is closely related with nutrient concentrations, particularly the presence of $\mathrm{Ca}^{2+}$ is of great importance. Contrary to this, in our experiment the $\mathrm{Zn}^{2+}$ content has decreased while $\mathrm{Ca}^{2+}$ increased in HA treated plants. The $\mathrm{Zn}^{2+}$ content decreased in HA treatment by $26 \%$ but did not show any significant differences from controls (Fig. 3. F). Some reports state that the antagonism between $\mathrm{Fe}^{3+}-\mathrm{Zn}^{2+}$, and $\mathrm{Zn}^{2+}$ interfered more with the absorption and translocation of $\mathrm{Fe}^{3+}$ rather than it did with $\mathrm{Cu}^{2+}$ and $\mathrm{Mn}^{2+}$. On the other hand, $\mathrm{Zn}^{2+}$ decreasing in broad bean root may be related with the $\mathrm{Fe}^{3+}$ causing the absorption of $\mathrm{Zn}^{2+}$ and its toxicity (Olsen, 1972).

\section{Manganese}

$\mathrm{Mn}^{2+}$ is known to show remarkable variation in its effects among plant species, stage of growth, different organs as well as ecosystem differences. $\mathrm{Mn}^{2+}$ content always increases with the increase of soil acidity. The broad bean grown under $\mathrm{pH} 6.5$ was not in suitable condition for its absorption in higher levels. $\mathrm{Mn}^{2+}$ content decreased as $26 \%$ in HA treatment compared to HO but did not differ significantly (Fig. 3. E). The result is also seems to be related to the antagonistic effect of $\mathrm{Ca}^{2+}$ and $\mathrm{Mg}^{2+}$ on $\mathrm{Mn}^{2+}$ uptake (Bozcuk, 2000). The other reason seems to be a toxic effect of $\mathrm{Mn}^{2+}$ on broad bean roots, since it shows toxicity in acidic soil and causes difficulties of $\mathrm{Fe}^{3+}$ uptake (Ergene, 1987).

\section{Copper}

Copper content in Vicia faba L. treated with HA decreased $27 \%$ but did differed significantly from controls (Fig. 3. G). Eyheraguibel et al., (2008) found that the $\mathrm{Cu}^{2+}$ increased significantly in $\mathrm{HA}$ treated maize plant roots by $14 \%$ compared to control. According to Mackowiak et al., (2001), in wheat plants grown with HEDTA, $\mathrm{Cu}^{2+}$ can not freely enter its root since HEDTA can make a stronger bond with $\mathrm{Cu}^{2+}$ compared to humic acid $\mathrm{Cu}^{2+}$ bonds. $\mathrm{Da}$ vid et al., (1994) stated that in tomato plants grown under low nutrient media, addition of humic acid causes increase of $\mathrm{Cu}^{2+}$ in its roots while $\mathrm{Cu}^{2+}$ concentration increased in tomato stems, under high nutrient treatment.

\section{Conclusions}

The results revealed that the plants grown with HA were significantly affected in both fresh and dry weights and development of roots, compared to plants grown under only HO. HA-treated roots were clearly affected, both, during germination (Fig. 1) and harvesting time (Fig. 2) as well in bio-mass.

These results confirm the data from the findings of various plants grown in different of humic acid media (resourced from leonardite, peat, fertilisers etc.) as well as various treatments (hydroponics, pot or field trials) that allowed us to understand the effectiveness of humic acid progress of root growth in Vicia faba L. Both fresh and dry weights increased respectively by $30.1 \%$ and $56.6 \%$ and differed significantly. The major contribution to the development of the roots seem to be increasing of potassium and sodium concentrations. The latter is supposed to be active in membrane potential hence may allow other possible nutrients to be absorbed which are not tested in this experiment.

Finally, from all these results we can conclude that humic acid application on broad bean affected the nutrient composition of roots. Humic acid increased $\mathrm{Na}^{+}$and $\mathrm{K}^{+}$ content significantly in broad bean to $86.4 \%$ and $111.4 \%$ respectively whereas $\mathrm{Ca}^{2+}$ content increased only by $32.5 \%$, but this was not significantly different at the 0.005 level (Fig. 3). We concluded that humic acid may increase the membrane permeability of root cells and cause uptake and transport of $\mathrm{Na}^{+}, \mathrm{K}^{+}, \mathrm{Ca}^{2+}, \mathrm{Fe}^{3+}$ and $\mathrm{Mn}^{2+}$. Many investigator have proposed the effect of humic substances on cell membranes to be by increasing permeability to some ions and decreasing others. Certain nutrient uptake increase in this membrane support the findings of significant increases in plasma membrane $\mathrm{H}^{+} \mathrm{ATPase}$ activity found in maize root (Pinton and Cesco, 1999).

Since humic substances have very complex structures, further study is still necessary to determine the relationship between the single compounds of humic acid a well as their biological activity in nutrient uptake. Our findings can be summarized as follows:

1. Humic acids have increased root development and growth in broad bean.

2. Humic acid increased steadily the content of $\mathrm{K}^{+}, \mathrm{Na}^{+}$ and $\mathrm{Ca}^{2+}$ in tissues but without the changes of the ratios of they have shown in $\mathrm{HO}$ treatment.

The nutrient analyses collected from broad bean roots needs more attention and further study with a better chemical identification and subsequent testing of pure compounds in relation to the chelating mechanisms, which may improve the uptake of unavailable nutrients present in soils.

\section{Acknowledgement}

We wish to thank Oya ALTUNGÖZ for evaluation flame photometer and atomic absorption spectrophotometer at the Izmir Technology Institute and research staff at A.T.A plant physiology laboratory at Marmara University, Faculty of Arts and Sciences. We wish also special thanks to Dr. Dorothy LÖSEL for her encouragement and English corrections of the text. 
86

\section{References}

Adani, F., Genevini, P., P. Zaccheo, and G. Zocchi (1998). The effect of commercial humic acid on tomato plant growth and mineral nutrition, Journal of Plant Nutrition. 21: 561-575.

Amtmann, A. and D. Sanders (1999). Mechanisms of $\mathrm{Na}^{+}$ uptake by plant cells. Advances in Botanical Research. 29: 76-112.

Anon., (2005). Statistical data bases of Fao. Available from http://faostat.fao.org/default.aspx?alias=faostatclassic

Arancon, N.Q., S. Lee, C.A. Edwards, and R. Atiyeh (2003). Effects of humic acids derived from cattle, food and paperwaste wermicompost on growth of greenhouse plants, Pedobiologia. 47: 741-744.

Atiyeh, R.M., S. Lee, C.A. Edwards, N.Q. Arancon and J.D. Metzger (2002). The influence of humic acids derived from earthworm-processed organic wastes on plant growth, Bioresource Technology. 84: 7-14.

Beadle, C.L. (1993). Growth analysis. Photosynthesis and production in a changing environment: a field and laboratory manual. (ed. by D.O. Hall, J.M.O. Scurlock, H.R. BoolharNordenkampf, R.C. Leegood and S.P. Long). pp. 22-46. Chapman \& Hall, London.

Benzyl, M.L. and M. Reuveni (1994). Cellular mechanisms of salt tolerance in plant cells. Hort. Rev. 16: 33-69.

Bidegain, R.A., M. Kaemmerer, M. Guiresse, M. Hafidi, F. Rey, P. Morard and J.C. Revel (2000). Effects of humic substances from composted or chemically decomposed poplar sawdust on mineral nutrition of ryegrass, Journal of Agricultural Science. 134: 259-267.

Bozcuk, S. (2000). Bitki fizyolojisi, Hacettepe Üniversitesi, Fen Edebiyat Fakültesi, Ankara, Türkiye 3. Baskı, Ankara.

Canellas, L.P., F.L. Olivares, A.L. Facanha-Okorokova, and A.R. Facanha (2002). Humic acids isolated from earthworm compost enhance root elongation, lateral root emergence, and plasma membrane $\mathrm{H}^{+}$-ATPase activity in maize roorts, Plant Physiology. 30: 1951-1957.

David, P.P., P.V. Nelson, and D.C. Sanders (1994). A humic acid improves growth of tomato seedling in solution culture, Journal of Plant Nutrition, 17: 173- 184.

Dursun, A., İ. Güvenç, and M. Turan (1999). Macro and micro nutrient contents of tomato and eggplant seedlings and their effects on seedling growthin relation to humic acid application, Improved Crop Quality by Nutrient Management, Anaç, D.; Martin-Prevel, P.Editors.; Kluwer Academic Publishers, Dordrecht, Boston, London.

Erdal, İ., M.A. Bozkurt, K.M. Çimrin, S. Karaca, and M. Sağlam (2000). Kireçli bir toprakta yetiştirilen mısır bitkisi gelişimi ve fosfor alımı üzerine hümik asit ve fosfor uygulamasının etkisi, Turk J Agric For. 24: 663-668.

Ergene, A.. (1987). Toprak Biliminin Esasları, Genişletilmiş 4. Baskı, Ankara Üniversitesi Basım Evi, Ziraat Fakültesi
Yayınları, No: 289, Ders Kitapları Serisi No: 47.

Eriş, A.; V. Şeniz (1997). Bahçe Bitkileri, Uludağ Üniversitesi Ziraat Fakültesi Ders Notları No: 28, III. Baskı, Bursa.

Eyheraguibel, B., J. Silvestre, and P. Morard (2008). Effects of humic substances derived from organic waste enhancement on the growth and mineral nutrition of maize, Bioresource Technology. 99: 4206-4212.

Ghabbour, E.A. and G. Davies (2001). Humic substances: Structures, models and functions, Royal Society of Chemistry, England.

Hare, P.D., W.A. Cress, and J.V. Staden (1998). Dissecting the roles of osmolytes accumulation during stress. Plant Cell Environ. 21: 535-553.

Hoagland, D.R. and D.I. Arnon (1950). The water-culture method for growing plants without soil. Univ. of California Agric. Exp. Stn. Circ. 347. Univ. of California, Berkeley, CA

Kabata-Pendias, A. and H. Pendias (2001). Trace elements in soils and plants (3rd ed.). Boca Raton, FL: CRC Press.

Kaçar, B. (1972). Bitki ve Toprağın Kimyasal Analizleri: III. Bitki Analizleri, Ankara Üniversitesi, Bizim Büro Basımevi, Ankara.

Kolsarıcı, Ö., M.D. Kaya, S. Day, A. İpek, S. Uranbey (2005). Farklı hümik asit dozlarının ayçiçeğinin (Helianthus annuus L.) çıkış ve fide gelişimi üzerine etkileri, Akdeniz Üniversitesi Ziraat Fakültesi Dergisi. 18: 151-155.

Kulikova, N.A., E.V. Stepanova, and O.V. Koroleva (2005). Mitigating activity of humic substances direct influence on biota, Use of humic substances to remediate polluted environments: From theory to practice, Perminova, I.V.; Hatfield, K. and Hertkorn, N.; Springer, Netherlands, pp. 285-310.

Larcher, W. (2003). Physiological Plant Ecology: Ecophysiology and stres physiology of functional groups, 4th. Edition, Springer, New York.

Lee, Y.S., R.J. Bartlett (1976). Stimulation of plant growth by humic substances, Soil Science Society of America Journal. 40: 876-879.

Linchan D. J. (1978). Humic acid and nutrient uptake by plants. Plant and Soil. 50: 663-670.

Lulakis, M.D., S.I. Petsas (1995). Effects of humic substances from vine-canes mature compost on tomato seedling growth, Bioresource Technology. 54: 179-182.

Mackey J.M.L. and A.M. Neal (1993). Harvesting, recording weight, area and length. In: Hendry GAF, Grime JP, eds. Methods in comparative plant ecology - a manual of laboratory methods. London: Chapman \& Hall.

Mackowiak, C.L., P.R. Grossl, and B.G. Bugbee (2001). Beneficial effects of humic acid on micronutrient availability to wheat, Soil Science Society of America Journal. 65: 17441750.

Malik, K.A. and F. Azam (1985). Effects of humic acids on wheat seedling growth, Environmental and Experimental 
Botany. 25: 245-252.

Mathers, H. (2002). Fertilizer practices: What's most important (Amounts, relative proportions and timing), Submitted to: NMPRO, pp. 1-9.

Mead, R. and R. N. Curnow (1983). Statistical methods in agriculturel and Experimental Biology Chapman and Hall, London.

Muscolo, A., F. Bovalo, F. Gionfriddo and S. Nardi (1999). Earthworm humic matter produces auxin-like effects on Daucus carota cell growth and nitrate metabolism, Soil Biology and Biochemistry. 31: 1303-1311.

O'Donnell, R.W. (1973). The Auxin-like effects of humic preparations from leonardite, Soil Science. 116: 106-112.

Olsen, S. R., (1972). Micronutrient interactions, in Micronutrients in Agriculture, Mortvedt, J. J., Giordano, P. M., and Lindsay, W. L., Eds., Soil Science Society of America, Madison, WI, pp. 243-264.

Pal, S. and M.B. Sengupta (1985). Nature and properties of humic acid prepared from different sources and its effects on nutrient availability. Plant and Soil. 88: 91-95.

Pinton, R., S.Cesco, G. Iacolettig, S. Astolfi, and Z. Varanini (1999). Modulation of NO3- uptake by water-extractable humic substances: Involvement of root plasma membrane $\mathrm{H}^{+}$-ATPase. Plant and Soil. 215: 155-161.

Qian, Y.L., S.J. Wilhelm, and K.B. Marcum (2001). Comparative response of two Kentucky bluegrass cultivars to salinity stress. Crop Sci. 41: 1895-1900.

Rehman, M.S., H. Miyake, and Y. Takeoka (2002). Effect of exogenous glycinebetaine on growth and ultrastructure of salt stressed rice seedlings (Oryza sativa L.). Plant Prod. Sci. 5: 33-44.

Roberts, M.J., S.P. Long, L.L. Tieszen and C.L. Beadle (1993). Measurement of plant biomass and net primary production of herbaceous vegetation. Photosynthesis and production in a changing environment: a field and laboratory manual.(ed. by D.O. Hall, J.M.O. Scurlock, H.R. Boolhar-Nordenkampf, R.C. Leegood and S.P. Long). pp. 1-21. Chapman \& Hall, London.

Sakamoto, A. and N. Murata (2002). The role of glycine betaine in the protection of plants from stress: Clues from transgenic plants. Plant, Cell Environ. 25: 163-171.

Samson, G. and S.A. Visser (1989). Surface-active effects of humic acids on potato cell membrane properties. Soil Biology and Biochemistry. 21: 343-347.
Schachtman, D. and W. Liu (1999). Molecular pieces to the puzzle of the interaction between potassium and sodium uptake in plants. Trends Plant Sci. 4: 281-287.

Sharif, M., R.A. Khattak and M.S. Sarir (2002). Effect of different levels of lignitic coal derived humic acid on growth of maize plants, Soil Science and Plant Analysis. 33: $3567-$ 3580 .

Stevenson, F.J. (1994). Humus Chemistry: Genesis, composition, reactions, 2nd edition, John Wiley and Sons, Inc, New York.

Subbarao, G.V., R.M. Wheeler, L.H. Levine and G.W. Stutte (2001). Glycine betaine accumulation, ionic and water relations of red beet at contrasting levels of sodium supply. J. Plant Physiol. 158: 767-776.

Tipping, E. (2002). Cation binding by humic substances, Cambridge University Press, Cambridge, U.K.

Türüdü, Ö.A. (1988). Bitki Beslenmesi ve Gübreleme Tekniği, Karadeniz Teknik Üniversitesi Basım Evi, Genel Yayın No: 121.

Tyerman S.D. and I.M. Skerrett (1999). Root ion channels and salinity. Scientiae Horticulturae. 78: 175-235.

Valdrighi, M.M., A. Pera, M. Agnolucci, S. Frassinetti, D. Lunardi, and G Valini (1996). Effects of compostderived humic acids on vegetable biomass production and microbial growth within a plant (Chichorium intybus)-soil system: A comparative study, Agriculture, Ecosystems and Environment. 58: 133-144.

White, P.J. (1999). The molecular mechanism of sodium influx to root cells. Trends in Plant Sciences. 4: 245-246.

Yılmaz, C. (2007). Hümik ve fülvik asit, Hasad Bitkisel Üretim, Ocak, 260: 74.

Zandonadi, D.B., L.P. Canellas and A.R. Facanha (2007). Indolacetic and humic acids induce lateral root development through a concerted plasmalemma and tonoplast $\mathrm{H}^{+}$pumps activation, Planta. 225: 1583-1595. 